\title{
DYNAMICS OF VOCATIVES IN AMERICAN, RUSSIAN AND BRITISH POLITICAL COMMUNICATION
}

\author{
Elena Yu. Nesterenko \\ Ural Federal University named after First President of Russia B.N. Eltsin, \\ Ekaterinburg, Russian Federation
}

\begin{abstract}
The paper analyses dynamic aspects of the vocative system in American, Russian and British political communication. The research considers inaugural addresses of the presidents of the USA (1789-2017), those of the presidents of the Russian Federation (1991-2012), Coronation speeches of British monarchs (1937 and 1953) as a special genre of political discourse. Vocatives used in these addresses and speeches are a source of linguistic analysis which reveals typological differences and similarities in American, Russian and British communication. The author characterizes linguistic-cultural peculiarities of political discourse of the USA, Russia and the United Kingdom. The author proves that status terms of address predominate in comparison to emotive ones in American and Russian presidents' political discourse; British monarchs usually omit forms of address in the epideictic genre discussed in the paper. The American presidents use various vocatives (special status vocatives and general status terms of address) in comparison to those used in inaugural addresses of the presidents of the Russian Federation (special status vocatives); the British monarchs use zero vocatives in the Coronation speeches. Functions of vocatives used in the addresses and speeches in question (appellative, contact-establishing and attitude-characterizing) contribute to shortening a social status distance between the leaders of the countries and addressees.

Key words: status vocative, political communication, political discourse, emotive vocative, zero vocative, inaugural address, speech etiquette, political speech etiquette.

Citation. Nesterenko E.Yu. Dynamics of Vocatives in American, Russian and British Political Communication. Vestnik Volgogradskogo gosudarstvennogo universiteta. Seriya 2, Yazykoznanie [Science Journal of Volgograd State University. Linguistics], 2017, vol. 16, no. 3, pp. 188-198. (in Russian). DOI: https://doi.org/10.15688/ jvolsu2.2017.3.19
\end{abstract}

УДК $82: 32$

ББК 81.006 .21

Дата поступления статьи: 28.02.2017

Дата принятия статьи: 28.04.2017

\section{ДИНАМИКА ОБРАЩЕНИЙ В АМЕРИКАНСКОЙ, РУССКОЙ И БРИТАНСКОЙ ПОЛИТИЧЕСКОЙ КОММУНИКАЦИИ}

\author{
Елена Юрьевна Нестеренко \\ Уральский федеральный университет имени первого Президента России Б.Н. Ельцина, \\ г. Екатеринбург, Российская Федерация
}

\begin{abstract}
Аннотация. В статье представлен анализ динамических аспектов поля статусных обращений в американской, русской и британской политической коммуникации. Как особый жанр политического дискурса в статье рассмотрены инаугурационные обращения президентов США (1789-2017 гг.), президентов Российской Федерации (1991-2012 гг.) и коронационные речи британских монархов (1937 и 1953 гг.), а обращения, чі использованные в них, послужили материалом для лингвистического анализа, в результате которого выявле을 типологические сходства и различия американской, русской и британской политической коммуникации, охарактеризованы лингвокультурные особенности политического дискурса США, России и Великобритании. Установлено, что в американском и русском президентском политическом дискурсе преобладают ста-


статусные и общие статусные) по сравнению с вокативами в речах президентов РФ (специальные статусные вокативы), в коронационных речах монархов Великобритании статусные обращения не зафиксированы. Выявленные функции обращений в рассмотренных речах (апеллятивная, контактоустанавливающая, оценочно-характеризующая) способствуют сокращению социально-статусной дистанции между лидером страны и аудиторией.

Ключевые слова: статусное обращение, политическая коммуникация, политический дискурс, эмотивное обращение, нулевой вокатив, инаугурационное обращение, речевой этикет, политический речевой этикет.

Цитирование. Нестеренко Е. Ю. Динамика обращений в американской, русской и британской политической коммуникации // Вестник Волгоградского государственного университета. Серия 2, Языкознание. 2017. - T. 16, № 3. - C. 188-198. - DOI: https://doi.org/10.15688/jvolsu2.2017.3.19

\section{1. Введение}

Обращения в политической коммуникации используются с целью социального регулирования и становятся значимым элементом в реализации иллокутивной цели высказывания. Сфере политической коммуникации принадлежат эпидейктические речи, в частности инаугурационные и коронационные речи.

Обращение главы государства к гражданам своей страны является публичным типом коммуникации, потому что сообщение передается в официальной обстановке человеком, обладающим высоким социальным статусом, что обусловливает статусно-ролевую природу речевого поведения выступающего, «предопределяет соблюдение установленных статусно-ролевых и ситуационно-коммуникативных норм» [Чудинов, 2012, с. 56]. Публичный вид коммуникации предполагает контактное общение, слушатели находятся в поле зрения говорящего. Однако во время инаугурации и коронации политик обращается не только к аудитории присутствующих на торжестве (прямая адресация), но и к массовому адресату, наблюдающему за церемонией (непрямая адресация), следовательно, происходит и непосредственное, и опосредованное общение, то есть общение со вторичным адресатом. Обращение, нацеленное на дистантного массового адресата (телезрителей, радиослушателей и пользователей Интернета), позволяет исследователям говорить о «театральном характере» политической коммуникации: массовый адресат наблюдает за происходящими событиями, как зритель в театpe, а политики исполняют определенные роли, которые обусловлены статусными отношениями [Захаров, 1998; Шейгал, 2004; Burke, 1966].
Политический дискурс направлен на установление контакта с адресатом. Условием успешности диалога между лидером страны и ее гражданами является коммуникативная заинтересованность (определение М.М. Бахтина), устанавливающая паритетность вне зависимости от социальных ролей и статуса. «Именно необходимость имитации паритетного общения диктует авторам политических текстов свои требования, которые предполагают использование многочисленных апеллятивов» [Руженцева, 2004, с. 250].

В статье анализируются статусные обращения в американской, русской и британской политической коммуникации. Материал для изучения составляют 58 инаугурационных обращений президентов США (1789-2017 гг.), 6 инаугурационных речей президентов России (1991-2012 гг.) и два коронационных обращения монархов Великобритании (Речи британских монархов рассматриваются с 1937 г., поскольку доступные для просмотра материалы датируются этим годом). В науке уже предпринималось сопоставительное изучение вокативов как единиц речевого этикета [Балакай, 2002; Ратмайр, 2003; Формановская, 2007; Формановская, Соколова, 2003]. Однако их динамика не становилась еще предметом специального исследования.

Цель данной статьи - рассмотреть в сопоставительном аспекте динамику статусных обращений в американской, британской и русской политической коммуникации, характеризуя лингвокультурные особенности политического дискурса.

При анализе языковых фактов мы опираемся на классификацию обращений, предложенную В.И. Карасиком, который выделяет статусные, антропонимические, дейктичес- 
кие и эмотивные вокативы. Статусные обращения делятся на общие ( $M r s, M r$ и др.) и специальные, которые распадаются на опосредованные (типа Your Majesty) и прямые (типа King). Кроме того, автор выделяет нулевой вокатив, употребление которого иногда свидетельствует о неопределенности статуса адресата [Карасик, 2002, с. 203]. Поскольку в инаугурационных и коронационных речах, как правило, используются статусные обращения, эмотивные обращения и нулевой вокатив, именно они и находятся в центре нашего исследовательского внимания.

\section{2. Обращения в инаугурационных речах президентов США}

В инаугурационных речах президентов США, первая из которых была произнесена в 1789 г., представлены как общие, так и специальные статусные обращения. Дж. Вашингтон в первом в истории США инаугурационном обращении использует вокатив Fellow-Citizens of the Senate and of the House of Representatives. Это специальное статусное обращение, единожды произнесенное во время инаугураций в США, состоит из десяти слов. Употребленный в начале речи, вокатив выполняет апеллятивную и контактоустанавливающую функции. В своей второй инаугурационной речи Дж. Вашингтон выбирает вокатив fellow citizens, который является самым частотным за всю историю проведения церемонии инаугурации в США (табл. 1).

Обращение my fellow citizens как вариант вышеупомянутого вокатива прозвучало на церемониях вступления главы государства в должность в 20 случаях, это второй по час- тотности вокатив. Употребление посессива ту позволяет адресанту акцентировать внимание слушателей на идее совместности. Глава государства использует прием солидаризации, посессив объединяет адресанта с аудиторией. Президенты использовали и другие варианты этого обращения: fellow citizens of the United States; my fellow citizens of the world; my fellow citizens of the world community; my fellow citizens of this great and good country we share together. Последний вокатив относится к специальным статусным обращениям и является окказиональным. Он включает в себя эпитеты great и good, подчеркивающие величие государства, к которому принадлежат адресаты и он сам, что акцентируется предикатом share и наречием together. Mecтоимение we позволяет президенту объединить себя со слушателями. Помимо апеллятивной и контактоустанавливающей функций, данное обращение выполняет оценочно-характеризующую функцию, что обусловлено выбором лексемы great - «important or powerful» (Macmillan, p. 622).

Президенты США употребляли также специальные статусные обращения $m y$ countrymen; fellow countrymen; my fellow countrymen; my countrymen, one and all; my dissatisfied fellow-countrymen; my fellow Americans; citizens of the United States. Двухкомпонентный вокатив my countrymen, в состав которого входит солидаризирующий посессив ту является одним из самых частотных в 1789- 1941 гг. (см. табл. 2). Обращение my dissatisfied fellow-countrymen выполняет оценочно-характеризующую функцию, поскольку эпитет dissatisfied передает разочарование народа страны, охваченной гражданской войной.

Таблииа 1

Частотность обращений в инаугурационных речах президентов США (1789-2017)

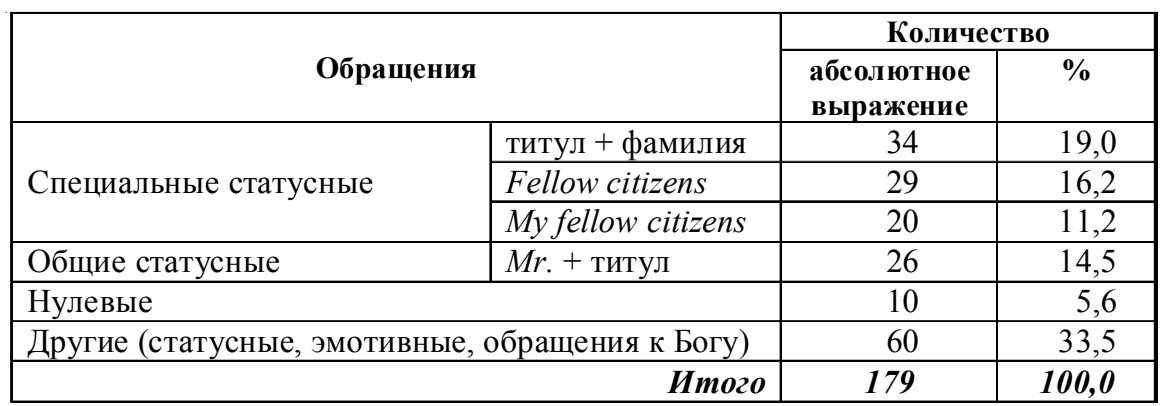


E.Ю. Нестеренко. Динамика обращений в политической коммуникации

Таблица 2

Частотность обращений в инаугурационных речах президентов США (1789-1941 гг.)

\begin{tabular}{|c|c|c|c|c|}
\hline \multirow{2}{*}{\multicolumn{2}{|c|}{ Обращения }} & \multirow[b]{2}{*}{ Датирование } & \multicolumn{2}{|c|}{ Количество } \\
\hline & & & $\begin{array}{l}\text { абсолютное } \\
\text { выражение }\end{array}$ & $\%$ \\
\hline \multirow{3}{*}{$\begin{array}{l}\text { Специальные } \\
\text { статусные }\end{array}$} & Fellow citizens & $\begin{array}{l}1793,1801,1805,1821,1825,1829, \\
1833,1837(2), 1841(2), 1845,1857, \\
1873,1877(3), 1881(2), 1885,1889, \\
1897\end{array}$ & 22 & 37,29 \\
\hline & My fellow citizens & $\begin{array}{l}1825,1837,1849,1893,1901(2), \\
1905,1909,1917\end{array}$ & 9 & 15,25 \\
\hline & My countrymen & $1853,1881,1921,1925,1929(4)$ & 8 & 13,56 \\
\hline \multicolumn{2}{|c|}{ Нулевые } & $\begin{array}{l}1797,1809,1813,1817,1849,1913, \\
1933,1937,1941\end{array}$ & 9 & 15,25 \\
\hline \multicolumn{3}{|c|}{ Другие (специальные статусные, эмотивные) } & 11 & 18,65 \\
\hline & & Итого & 59 & 100,00 \\
\hline
\end{tabular}

Варианты вокативов fellow citizens и countrymen встречаются в инаугурационных посланиях XVIII - первой половины XX в. и являются обращениями-синонимами (Oxford Synonyms, Oxford Antonyms). Использование данных обращений на протяжении более двух столетий американской истории показывает, что президент США во время инаугурационной речи пытается продемонстрировать единение с нацией, которая рассматривается как полноправный участник этого торжественного момента.

Данные словарей современного английского языка позволяют объяснить, почему именно fellow было произнесено в 39 из 58 инаугурационных речей американских президентов. В словаре А. Хорнби fellow определяется как «used to describe somebody who is the same as you in some way, or in the same situation» (Hornby, p. 466). В словаре издательства «Макмиллан» встречается следующая дефиниция fellow: «used for talking about people who are similar to you or in the same situation as you» (Macmillan, p. 513). Словарь Уордсмит предлагает следующее определение этого слова: «a person of similar class or status to one's own, peer» (Wordsmith). Выбор данной лексемы в качестве обращения позволяет говорящему минимизировать социальную дистанцию. Несмотря на статусное неравноправие коммуникантов, вышестоящий участник общения, как отмечает М. Грейшон, может переключать социальную дистанцию, которая является динамичной, таким способом удаляя или приближая партнера по коммуникации [Grayshon, 1977, p. 61].
В инаугурационных посланиях встречаются специальные статусные обращения Reverend Clergy (его произносят три президента), Senators, Representatives, judges (они прозвучали в речи Ратерфорда Хейса), members of the United States Congress. К статусным вокативам относится обращение distinguished guests, отмеченное в речах двух президентов.

В инаугурационных посланиях XVIII первой половине XX в. самыми частотными являются специальные статусные обращения fellow citizens и my fellow citizens. Во второй половине XX и начале XXI столетий обращение fellow citizens становится шестым по частотности, вокатив my fellow citizens - самым частотным, а вторым по частотности обращением становится общий статусный вокатив Mr. Chief Justice (см. табл. 3). Это двухкомпонентный вокатив, состоящий из общего обращения $M r$, которое определяется как «а conventional title of courtesy, usually abbreviated and placed before a man's last name or title of office» (Wordsmith), и официального титула Верховного судьи США Chief Justice. Необходимость употребления общего вокатива перед титулом обусловлена правилами этикета: «Англоязычный этикет требует употребления общих вокативов в определенных официальных ситуациях с указанием должности человека без употребления фамилии: Mr. President, Mr. Secretary, Mr. Speaker. Список таких должностей ограничен и распространяется только в отношении социально-престижных позиций» [Карасик, 2002, с. 196]. Вокатив Mr. Chief Justice зафиксирован в 10 из 58 ина- 
Частотность обращений в инаугурационных речах президентов США (1945-2017 гг.)

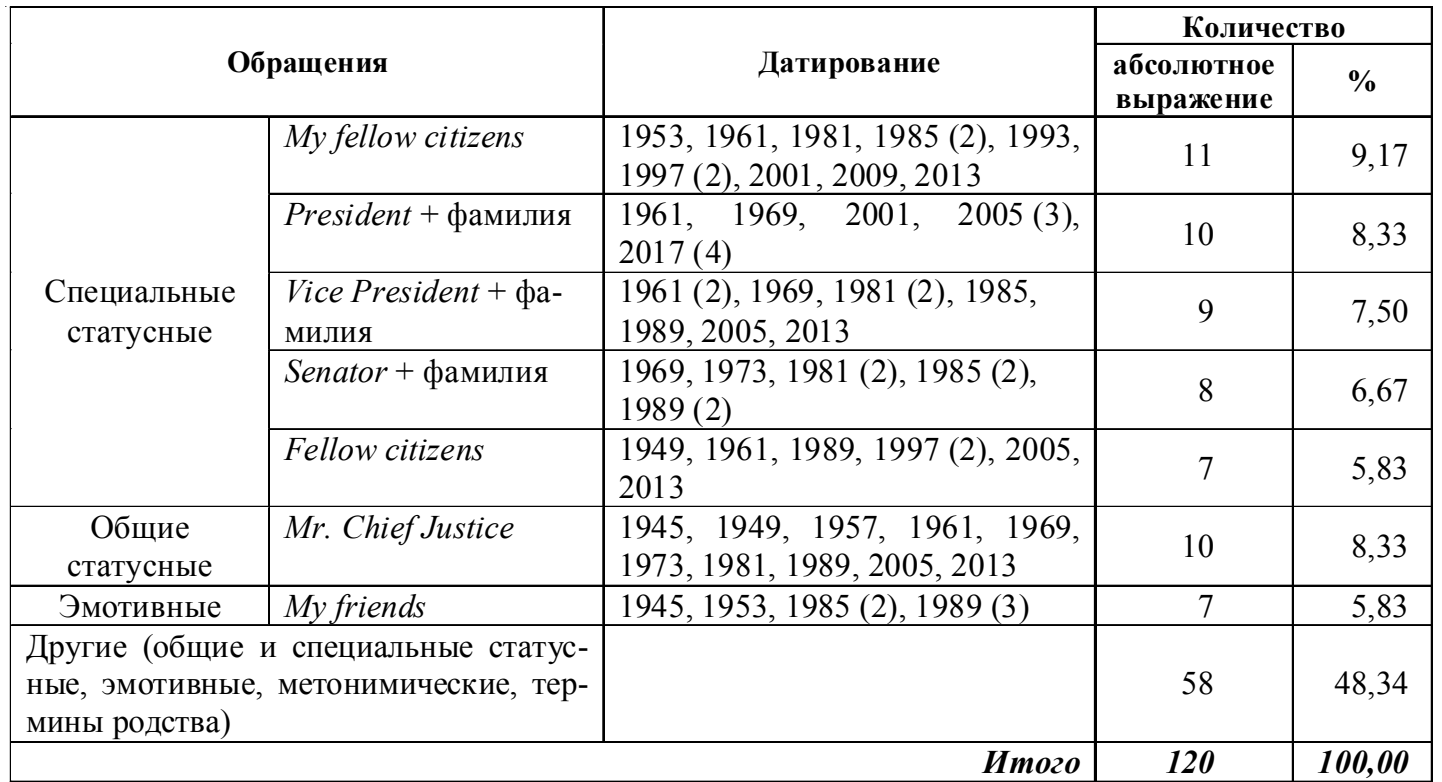

угурационных обращений, употребляется в начале речи и выполняет апеллятивную и контактоустанавливающую функции.

Частотность данного обращения можно объяснить традицией, существующей в США с 1797 г., согласно которой Председатель Верховного суда страны приводит президента к присяге. Обращаясь к будущему президенту, он использует нулевой вокатив. Выбор данного обращения может быть обусловлен стремлением Председателя Верховного суда сократить социальную дистанцию, что допустимо в стране, считающей себя самой демократической в мире.

Впервые обращение Mr. Chief Justice использовал в своей речи Франклин Рузвельт в 1945 году. Он начал свое обращение словами:

(1) Mr Chief Justice, Mr Vice President, my friends, you will understand and, I believe, agree with my wish... (Roosevelt 1945).

В данном примере обнаруживается также общий статусный вокатив Mr. Vice President. Это двухкомпонентное обращение, выполняющее апеллятивную и контактоустанавливающую функции. Те же функции оно реализует и в инаугурационных обращениях еще четырех президентов:

(2) Mr Vice President, Mr Chief Justice, and fellow citizens, I accept with humility... (Truman 1949).
(3) Mr Chairman, Mr Vice President, Mr Chief Justice, Mr Speaker, members of my family and friends, my countrymen, and the friends of my country, wherever they may be... (Eisenhower 1957).

(4) Senator Dirksen, Mr. Chief Justice, Mr. Vice President, President Johnson, Vice President Humphrey, my fellow Americans - and my fellow citizens of the world community: I ask you... (Nixon 1969).

(5) Mr. Vice President, Mr. Speaker, Mr. Chief Justice, Senator Cook, Mrs. Eisenhower, and my fellow citizens of this great and good country we share together: When we met... (Nixon 1973).

В приведенных выше примерах $(3,5)$ кроме обращения $M r$. Vice President употреблены три других общих статусных обращения Mr Chairman, Mrs Eisenhower и Mr. Speaker. Обращение $M r$. Speaker используют в своих инаугурационных обращениях президенты Джон Кеннеди и Джордж Герберт Уокер Буш, последний из которых произносит еще одно общее статусное обращение - Mr Majority Leader.

В период с 1945 по 2017 г. в инаугурационных обращениях американских президентов достаточно распространенными (табл. 3) стали специальные статусные обращения, строящиеся по модели «титул President / Vice President / Senator / Speaker / Chief Justice / Congressman / Reverend + фамилия»: 
(6) Senator Hatfield, Mr. Chief Justice, Mr. President, Vice President Bush, Vice President Mondale, Senator Baker, Speaker O'Neill, Reverend Moomaw, and my fellow citizens: To a few of us... (Reagan 1981).

(7) Senator Mathias, Chief Justice Burger, Vice President Bush, Speaker O'Neill, Senator Dole, Reverend Clergy, members of my family and friends, and my fellow citizens: This day... (Reagan 1985).

(8) Mr. Chief Justice, Mr. President, Vice President Quayle, Senator Mitchell, Speaker Wright, Senator Dole, Congressman Michel, and fellow citizens, neighbors, and friends: There is a man here... (Bush 1989).

Дж.Г.У. Буш в 1989 г. произнес наибольшее количество вокативов - 20, в том числе 7 специальных статусных, 6 общих статусных, 5 эмотивных и два обращения к Богу. До 1945 г. самое большое количество вокативов фиксируется в речи Р.Б. Хейса (6). Все они являются специальными статусными обращениями. До 1945 г. президенты использовали 59 обращений в 39 инаугурационных речах (12 вокатива в одном послании), в $1945-$ 2017 гг. - 120 вокативов в 19 речах (6-7 вокативов в одной речи). Это может свидетельствовать о том, что во второй половине XX столетия президенты, используя большое количество обращений разного типа, стремятся создать общее с адресатами коммуникативное пространство.

Кроме статусных обращений в инаугурационных речах американских президентов встречается большое количество эмотивных вокативов, самым частотным из которых является обращение my friends. Оно употребляется в 7 контекстах, а Джордж Герберт Уокер Буш использует это обращение трижды, он также дважды произнес эмоциональное обращение friends. В инаугурационных посланиях президентов фиксируется еще одно эмотивное обращение - the friends of my country. Эмотивные вокативы позволяют не только привлечь внимание адресата, но и расположить его к себе, сокращая социально-статусную дистанцию.

Некоторые президенты США в инаугурационных посланиях апеллируют к Богу:

(9) Almighty God, as we stand here... (Eisenhower 1953) .
(10) Heavenly Father, we bow our heads and thank You for Your love (Bush 1989).

(11) Help us to remember it, Lord (Bush 1989).

Многие этнологи подчеркивают такую характеристику американской нации, как религиозность. Тем не менее некоторые авторы считают, что в американском обществе широкое распространение получила «гражданская религия» (термин введен Жан-Жаком Русco), которая является своего рода слиянием религии и политики. Самой деятельной фигурой этой религии выступает президент, участвующий во всех главных ритуалах гражданской религии, основным из которых является инаугурация [Садуов, 2012, с. 42-45]. Обращения к Богу носят такой же ритуальный характер, как и это церемониальное событие.

\section{3. Обращения в инаугурационных речах президентов Российской Федерации}

Традиция инаугурационных обращений президентов США сложилась в конце XVIII столетия, были выработаны определенные принципы и нормы функционирования этого политического жанра. В российской политической коммуникации это новый жанр, который находится на стадии формирования в системе политического дискурса. М.В. Гаврилова считает, что первым инаугурационным обращением российского президента можно считать выступление Б.Н. Ельцина в 1991 г., когда была учреждена должность президента и впервые проводилась торжественная церемония вступления в должность главы государства Российской Федерации [Гаврилова, 2004, с. 43-69]. Перед принесением присяги Б.Н. Ельцин обратился к нации Граждане Российской Федераиии! Такое специальное статусное обращение показывает, по мнению Е.И. Шейгал, что нация является полноправным коммуникантом этого статусно-индексального общения на уровне «политик - народ» [Шейгал, 2004, c. 235]. Употребляя слово граждане, Б.Н. Ельцин использует коммуникативный прием сплочения. Будучи гражданином РФ, президент является неотъемлемой частью народа, что и подчеркивается обращением граждане. В начале послания первого Президента РФ фиксируются специальные статусные обращения уважаемые граждане России, народные депу- 
тать, соотечественники и уважаемье гос$m u$. Они выполняют апеллятивную и контактоустанавливающую функции. В конце речи Б.Н. Ельцин использует специальный статусный вокатив уважаемье сограждане, который содержит производное существительное с приставкой со-, означающей общее участие в чемнибудь, совместность.

Инаугурационное обращение первого Президента России, прозвучавшее 9 августа 1996 г., по мнению Р. Сзимула, можно условно отнести к первой инаугурационной речи в истории страны [Szymula, 2014, p. 118]. Это послание считают самым коротким (всего 33 слова). Во время телевизионного обращения употреблена нулевая форма вокатива, которая может свидетельствовать о стремлении сократить социальную дистанцию и перейти на персональный уровень общения.

Однако отдельные зарубежные исследователи и журналисты [Szymula, 2016; Гальперович] полагают, что первая инаугурационная речь была произнесена В.В. Путиным, которого можно назвать автором этого жанра в России. Можно сказать, что В.В. Путин заложил традицию произнесения достаточно продолжительной речи (по сравнению с короткими инаугурационными посланиями Б.Н. Ельцина), которую он начинает, используя специальное статусное обращение уважаемые граждане России и эмотивное дорогие друзья:

(12) Уважаемые граждане России, дорогие друзья! Сегодня я обращаюсь к вам, именно к вам, потому что вы доверили мне высший государственный пост в стране... (Послания, 7 мая 2000 г.).

Вокатив граждане с этикетной модификацией уважаемые подчеркивает, что речь обращена не только к непосредственному адресату, присутствующему на торжественной церемонии, но и к косвенному - жителям всей страны, наблюдающим за этим ритуалом. Обращение дорогие друзья с коннотацией «я свой» используется для солидаризации нации. В данном случае адресант демонстрирует общность своей позиции с адресатом. Этот вокатив реализует оценочно-характеризующую функцию.

Во всех инаугурационных обращениях В.В. Путина используются одни и те же вокативные конструкции. Иногда он вторично употребляет одно из этих обращений для привлечения внимания адресата к важной информации и для перехода от одной темы к другой. Таким образом, можно сделать вывод о том, что в инаугурационной речи - формирующемся в России жанре политического дискурса - преобладают статусные обращения (табл. 4).

Сравнивая американский и русский инаугурационный дискурс, можно отметить, что в инаугурационных речах президентов США и России преобладают статусные обращения, но в России используются только специальные статусные вокативы, а в США со второй половины XX столетия возрастает употребительность общих статусных обращений.

\section{4. Обращения в коронационных речах монархов Великобритании}

В России и США существует «одновершинная президентская» модель власти, поэтому ритуалы сосредоточены в руках избранного народом Президента. В Великобритании «двуглавая модель “Монарх - Премьер-ми-

Частотность обращений в инаугурационных речах президентов России

Таблиияа 4

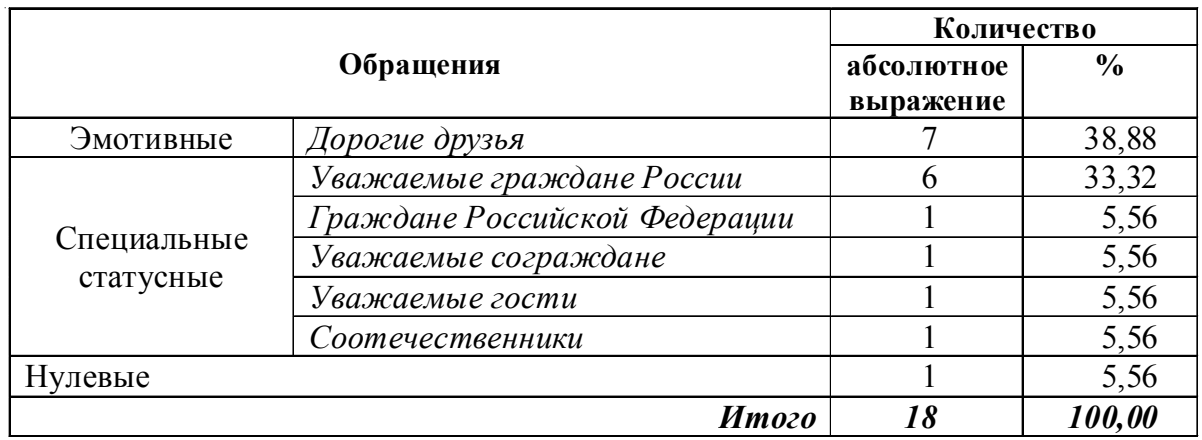


нистр"», при этом ритуалы закреплены за монархом [Юданова, 2003, с. 88].

Георг VI во время коронации 12 мая 1937 г. использовал нулевой вокатив. Архиепископ Кентерберийский, который проводил церемонию коронации 2 июня 1953 г., обратился к Елизавете II, применив общее статусное обращение Madam, имеющее апеллятивную и контактоустанавливающую функции, которое входит в систему лексических единиц британского речевого этикета. Это подтверждается словарным толкованием слова Madam: «a gentlewoman; - an appellation or courteous form of address to a lady, especially an elderly or a married lady; - much used in the address» (Websters). Использование слова gentlewoman означает, что речь идет о женщине, занимающей высокое положение на социальной лестнице. Именно такую дефиницию дает слову Madam онлайн-словарь компании MerriamWebster: «used when you are speaking to a woman who has a high rank or position» (MerriamWebster Dictionary). Таким образом, употребление Архиепископом Кентерберийским вокатива Madam подчеркивает, что в данном случае адресат имеет более высокий социальный статус, чем адресант. На этой церемонии королева Елизавета II произнесла речь, которую начала следующим образом:

(13) When I spoke to you last, I asked you all ... (Queen Elizabeth II 1953).

Елизавета II, так же как и Георг VI, использует нулевую форму обращения.

\section{5. Выводы}

Проанализировав вокативы, использованные во время инаугурации президентами США и России, и вокативы, которые употребляли во время церемонии коронации британские монархи, можно сделать вывод о том, что президенты США и России преимущественно применяют статусные обращения, а британские монархи предпочитают нулевую форму обращения. В США президенты использовали 46 различных видов вокативов, в том числе 31 тип специальных статусных и 7 видов общих статусных обращений, в России лидеры страны употребляли 5 типов специальных статусных вокативов, в Великобритании в коронационных речах статусные обращения зафиксированы не были. В США самое большое количество обращений в речи - 20, в России - 5, в Великобритании - 1. В США, в отличие от России и Великобритании, частотность обращений меняется. В 1789-1941 гг. самыми частотными были специальные статусные вокативы fellow citizens и my fellow citizens, в 1945-2017 гг. my fellow citizens и общее статусное обращение Mr. Chief Justice. В России в 1991-2012 гг. самыми частотными являются специальный статусный вокатив уважаемые граждане России и эмотивное обращение дорогие друзья, в Великобритании - нулевой вокатив. В США до 1945 г. президенты использовали в одной речи 1-2 обращения, после 1945 г. 6-7 вокативов, в России - три вокатива, в Великобритании - один. Во всех речах лидеров трех государств вступительные обращения (использованные в начале посланий) выполняют апеллятивную и контактоустанавливающую функции.

Суммируя наши наблюдения над употреблением вокативов в этом эпидейктическом жанре политического дискурса США, России и Великобритании, приходим к выводу о том, что использование того или иного вида вокатива помогает главам этих государств сократить социально-статусную дистанцию. Помимо того, что обращение выполняет апеллятивную, контактоустанавливающую и оценочнохарактеризующую функции, оно обладает прагматическим потенциалом и маркирует социальное пространство.

\section{СПИСОК ЛИТЕРАТУРЫ}

Балакай, А. Г. Русский речевой этикет и принципы его лексикографического описания / А. Г. Балакай. - Новокузнецк : Изд-во Новокузнец. гос. пед. ун-та, 2002. - 228 с.

Гаврилова, М. В. Когнитивные и риторические основы президентской речи (на материале выступлений В.В. Путина и Б.Н. Ельцина) / М. В. Гаврилова. - СПб. : Филол. фак. СПбГУ, 2004. - 296 с.

Гальперович, Д. Инаугурация Дмитрия Медведева - пятая в новейшей российской истории / Д. Гальперович // Сайт «Радио Свобода». - Электрон. текстовые дан. - Режим доступа: https://www.svoboda. org/a/446621.html (дата обращения: 15.09.2016). - Загл. с экрана. 
Захаров, А. В. Народные образы власти / А. В. Захаров // Полис. Политические исследования. - 1998. - № 1. - С. 23-35.

Карасик, В. И. Язык социального статуса / В. И. Карасик. - М. : ИТДГК «Гнозис», 2002. -333 с.

Ратмайр, Р. Прагматика извинения: сравнительное исследование на материале русского языка и русской культуры / Р. Ратмайр ; пер. с нем. Е. Араловой. - М. : Языки славянской культуры, 2003. $-272 \mathrm{c}$.

Руженцева, Н. Б. Дискредитирующие тактики и приемы в российском политическом дискурсе / Н. Б. Руженцева. - Екатеринбург : Урал. гос. пед. ун-т, 2004. - 294 с.

Садуов, Р. Т. Феномен политического дискурса Барака Х. Обамы: лингвокультурологический и семиотический анализ / Р. Т. Садуов. - Уфа : РИЦ БашГУ, 2012. - 136 с.

Формановская, Н. И. Речевое взаимодействие: коммуникация и прагматика / Н. И. Формановская. - М. : ИКАР, 2007. - 480 с.

Формановская, Н. И. Речевой этикет. Русскофранцузские соответствия / Н. И. Формановская, Г. Г. Соколова. - М. : Высшая школа, 2003. - 95 с.

Чудинов, А. П. Дискурсивные характеристики политической коммуникации / А. П. Чудинов // Политическая лингвистика. - 2012. - Вып. 2 (40). C. 53-59.

Шейгал, Е. И. Семиотика политического дискурса / Е. И. Шейгал. - М. : Гнозис, 2004. - 326 с.

Юданова, Е. Т. Суггестивная функция языковых средств англоязычного политического дискурca : дис. ... канд. филол. наук / Юданова Елена Тимофеевна. - СПб., 2003. - 181 c.

Burke, K. Language as Symbolic Action / K. Burke. Berkeley, CA : Univ. of California Press, 1966. -532 p.

Grayshon, M. Towards a Social Grammar of Language / M. Grayshon. - The Hague : Mouton, 1977. $-143 \mathrm{p}$.

Szymula, R. Особенности русского политического дискурса: (на примере инаугурационной речи президента Владимира Владимировича Путина, 2012 год) / R. Szymula // Acta Neophilologica. - 2014. XVI (1). - P. 115-125.

Szymula, R. Реализация концепта «президент» в инаугурационных речах В.В. Путина / R. Szymula // Linguodidactica. - 2016. - XX. - P. 305-317.

\section{ИСТОЧНИКИ}

Послания - Послания, обращения. История Современной России. - Электрон. текстовые дан. Режим доступа: http://prohistory.ru/ru/documents/ by_category/16 (дата обращения: 21.05.2017). - Загл. с экрана.
Bush 1989 - George Bush: Inaugural Address January 20, 1989. - Electronic text data. - Mode of access: http://www.bartleby.com (date of access: 07.08.2016). - Title from screen.

Eisenhower 1953 - Dwight, D. Eisenhower: First Inaugural Address January 20, 1953. - Electronic text data. - Mode of access: http://www.bartleby.com (date of access: 07.08.2016). - Title from screen.

Eisenhower 1957 - Dwight, D. Eisenhower: Second Inaugural Address January 21, 1957. - Electronic text data. - Mode of access: http://www. bartleby.com (date of access: 07.08.2016). - Title from screen.

Nixon 1969 - Richard Milhous Nixon: First Inaugural Address January 20, 1969. - Electronic text data. - Mode of access: http://www.bartleby.com (date of access: 07.08.2016). - Title from screen.

Nixon 1973 - Richard Milhous Nixon: Second Inaugural Address January 20, 1973. - Electronic text data. - Mode of access: http://www.bartleby.com (date of access: 07.08.2016). - Title from screen.

Queen Elizabeth II 1953 - HM Queen Elizabeth II Coronation Day Speech - 2 June 1953. - Electronic data. - Mode of access: https://www.youtube.com/ watch? $\mathrm{v}=\mathrm{S} 2$ pgmKeGEZg (date of access: 07.08.2016). Title from screen.

Reagan 1981 - Reagan Ronald: First Inaugural Address January 20, 1981. - Electronic text data. Mode of access: http://www.bartleby.com (date of access: 07.08.2016). - Title from screen.

Reagan 1985 - Reagan Ronald: Second Inaugural Address January 21, 1985. - Electronic text data. - Mode of access: https://www.youtube.com/ watch? $\mathrm{v}=\mathrm{iQwcAxgSW7s}$ (date of access: 07.08.2016). Title from screen.

Roosevelt 1945 - Roosevelt Franklin D.: Inaugural Address January 20, 1945. - Electronic text data. - Mode of access: http://www.bartleby.com (date of access: 07.08.2016). - Title from screen.

Truman 1949 - Truman Harry S.: Inaugural Address January 20, 1949. - Electronic text data. Mode of access: http://www.bartleby.com (date of access: 07.08.2016). - Title from screen.

\section{СЛОВАРИ}

Hornby - Hornby, A. S. Oxford Advanced Learner' Dictionary of Current English / A. S. Hornby. Oxford: Oxford University Press, 2000. - 1540 p.

Macmillan - Macmillan English Dictionary for Advanced Learners. - Oxford : Bloomsberry Publishers Ltd, 2002. - $1692 \mathrm{p}$.

Merriam-Webster Dictionary - MerriamWebster Dictionary. - Electronic text data. - Mode of access: http://www.merriam-webster.com/ (date of access: 12.09.2016). - Title from screen. 
Oxford Synonyms, Oxford Antonyms - Oxford Synonyms, Oxford Antonyms. - Electronic text data. Mode of access: www.thesaurus.com (date of access: 17.09.2016). - Title from screen.

Websters - Webster's Online Dictionary. Electronic text data. - Mode of access: http://www. websters-online-dictionary.org (date of access: 15.09. 2016). - Title from screen.

Wordsmyth - Wordsmyth. The Premier Educational Dictionary-Thesaurus. - Electronic text data. - Mode of access: http://www.wordsmyth.net (date of access: 12.09.2016). - Title from screen.

\section{REFERENCES}

Balakay A.G. Russkiy rechevoy etiket i printsipy ego leksikograficheskogo opisaniya [Russian Speech Etiquette and Principles of its Lexicographic Description]. Novokuznetsk, Novokuznetsk. gos. ped. un-t Publ., 2002. 228 p.

Gavrilova M.V. Kognitivnye $i$ ritoricheskie osnovy prezidentskoy rechi (na materiale vystupleniy V.V. Putina i B.N. Eltsina) [Cognitive and Rhetorical Foundations of the Presidential Speech (Case Studies of Vladimir Putin's and Boris Eltsin's Speeches)]. Saint Petersburg, Filologicheskiy fakultet SPbGU Publ., 2004. 296 p.

Galperovich D. Inauguratsiya Dmitriya Medvedeva - pyataya $\mathrm{v}$ noveyshey rossiyskoy istorii [Inauguarion of Dmitry Medvedev - the $5^{\text {th }}$ in the Modern Russian History]. Sayt "Radio Svoboda» [Radio Svoboda Website]. URL: https://www. svoboda.org/a/ 446621.html. (accessed September 15, 2016).

Zakharov A.V. Narodnye obrazy vlasti [Folk Images of Power]. Polis. Politicheskiye issledovaniya [Polis. Political Studies], 1998, no. 1, pp. 23-35.

Karasik V. I. Yazyk sotsialnogo statusa [The Language of Social Status]. Moscow, Gnozis Publ., 2002.333 p.

Ratmayr R. Pragmatika izvineniya: sravnitelnoe issledovanie na materiale russkogo yazyka i russkoy kultury [The Pragmatics of Apology: a Comparative Study on the Material of the Russian Language and Russian Culture]. Transl. by E. Aralova. Moscow, Yazyki slavyanskoy kultury Publ., 2003. 272 p.

Ruzhentseva N.B. Diskreditiruyushchie taktiki $i$ priemy $v$ rossiyskom politicheskom diskurse [Discrediting Tactics and Techniques in Russian Political Discourse]. Ekaterinburg, Ural. gos. ped. un-t Publ., 2004. 294 p.

Saduov R.T. Fenomen politicheskogo diskursa Baraka Kh. Obamy: lingvokulturologicheskiy $i$ semioticheskiy analiz [The Phenomenon of Barack H. Obama's Political Discourse: Linguistic, Cultural and Semiotic Analysis]. Ufa, RITs BashGU Publ., 2012. 136 p.
Formanovskaya N.I. Rechevoe vzaimodeystvie: kommunikatsiya i pragmatika [Speech Interaction: Communication and Pragmatics]. Moscow, IKAR Publ., 2007. 480 p.

Formanovskaya N.I., Sokolova G.G. Rechevoy etiket. Russko-frantsuzskie sootvetstviya [Speech Etiquette. Russian-French Equivalents]. Moscow, Vysshaya shkola Publ., 2003. 95 p.

Chudinov A.P. Diskursivnye kharakteristiki politicheskoy kommunikatsii [Discourse Characteristics of Political Communication]. Politicheskaya lingvistika [Political Linguistics Journal], 2012, no. 2 (40), pp. 53-59. Sheygal E.I. Semiotika politicheskogo diskursa [Semiotics of Political Discourse]. Moscow, Gnozis Publ., 2004. 326 p.

Yudanova E.T. Suggestivnaya funktsiya yazykovykh sredstv angloyazychnogo politicheskogo diskursa: dis. ... kand. filol. nauk [Suggestive Function of Linguistic Modes of English Political Discourse. Cand. philol. sci. diss.]. Saint Petersburg, 2003. $181 \mathrm{p}$.

Burke K. Language as Symbolic Action. Berkeley, CA: Univ. of California Press Publ., 1966. 532 p.

Grayshon M. Towards a Social Grammar of Language. The Hague, Mouton Publ., 1977. 143 p.

Szymula R. Osobennosti russkogo politicheskogo diskursa: (na primere inauguratsionnoy rechi prezidenta Vladimira Vladimirovicha Putina, 2012 god) [Distinctive Features of Russian Political Discourse (Based on President Putin's Inaugural Speech, 2012)]. Acta Neophilologica, 2014, no. 16/1, pp. 115-125.

Szymula R. Realizatsiya kontsepta «prezident» $\mathrm{v}$ inauguratsionnykh rechakh V.V. Putina [The Realisation of Concept "President" in Inaugural Speeches of V.V. Putin]. Linguodidactica, 2016, vol. XX, pp. 305-317. DOI: 10.15290/lingdid.2016.20.21.

\section{SOURCES}

Poslaniya, obrashcheniya. Istoriya Sovremennoy Rossii [Messages, Addresses. History of Contemporary Russia]. URL: http://prohistory.ru/ru/ documents/by_category/16. (accessed August 7, 2016).

George Bush: Inaugural Address January 20, 1989. URL: http://www.bartleby.com. (accessed August 7, 2016).

Dwight D. Eisenhower: First Inaugural Address January 20, 1953. URL: http://www.bartleby.com. (accessed August 7, 2016).

Dwight D. Eisenhower: Second Inaugural Address January 21, 1957. URL: http://www.bartleby. com. (accessed August 7, 2016).

Richard Milhous Nixon: First Inaugural Address January 20, 1969. URL: http://www.bartleby. com. (accessed August 7, 2016). 


\section{МАТЕРИАЛЫ И СООБЩЕНИЯ}

Richard Milhous Nixon: Second Inaugural Address January 20, 1973. URL: http://www.bartleby. com. (accessed August 7, 2016).

HM Queen Elizabeth II - Coronation Day Speech-2 June 1953. URL: https://www.youtube. com/ watch?v=S2pgmKeGEZg. (accessed August 7, 2016).

Reagan Ronald: First Inaugural Address January 20, 1981. URL: http://www.bartleby.com. (accessed August 7, 2016).

Reagan Ronald: Seconnd Inaugural Address January 21, 1985. URL: https://www.youtube.com/ watch? $=\mathrm{iQwcAxgSW7}$ s. (accessed August 7, 2016).

Roosevelt Franklin D.: Inaugural Address January 20, 1945. URL: http://www.bartleby.com. (accessed August 7, 2016).

Truman Harry S.: Inaugural Address January 20, 1949. URL: http://www.bartleby.com. (accessed August 7, 2016).

\section{DICTIONARIES}

Hornby A.S. Oxford Advanced Learner' Dictionary of Current English. Oxford, Oxford University Press, 2000. $1540 \mathrm{p}$.

Macmillan English Dictionary for Advanced Learners. Oxford, Bloomsberry Publishers Ltd, 2002. $1692 \mathrm{p}$.

Merriam-Webster Dictionary. URL: http://www. merriam-webster.com. (accessed September 12, 2016).

Oxford Synonyms, Oxford Antonyms. URL: www.thesaurus.com. (accessed September 17, 2016).

Webster's Online Dictionary. URL: http://www. websters-online-dictionary.org. (accessed September 15, 2016).

Wordsmyth. The Premier Educational Dictionary-Thesaurus. URL: http://www.wordsmyth. net. (accessed September 12, 2016).

\section{Information about the Author}

Elena Yu. Nesterenko, Assistant Professor, Department of Foreign Languages and Educational Technology, Ural Federal University named after First President of Russia B.N. Eltsin, Prosp. Lenina, 51, 620002 Ekaterinburg, Russian Federation, elena.nester.00@mail.ru, http://orcid.org/0000-0002-0486-0708

\section{Информация об авторе}

Елена Юрьевна Нестеренко, старший преподаватель кафедры иностранных языков и образовательных технологий, Уральский федеральный университет имени первого Президента России Б.Н. Ельцина, просп. Ленина, 51, 620002 г. Екатеринбург, Российская Федерации, elena.nester.00@mail.ru, http://orcid.org/0000-0002-0486-0708 